\title{
Combined Effect of Fly-Ash and Ferrochrome Ash as Partial Replacement of Cement on Mechanical Properties of Concrete
}

\author{
Tribikram Mohanty ${ }^{1}$, Sauna Majhi ${ }^{2}$, Purnachandra $\mathrm{Saha}^{3}$, Bitanjaya Das ${ }^{4}$ \\ ${ }^{1}$ Assistant Professor, School of Civil Engineering, KIIT Deemed to be University, Bhubaneswar, India, \\ ${ }^{2}$ Postgraduate student, School of Civil Engineering, KIIT Deemed to be University, Bhubaneswar, India, (1654016@kiit.ac.in) \\ ${ }^{3}$ Senior Associate Professor, School of Civil Engineering, KIIT Deemed to be University, Bhubaneswar, India, \\ (dr.purnasaha@gmail.com) \\ ${ }^{4}$ Senior Professor, School of Civil Engineering, KIIT Deemed to be University, Bhubaneswar, India, (bdasfce@kiit.ac)
}

\begin{abstract}
Due to rapid industrialization extensive quantity of waste materials like fly ash, silica fume, rice ash husk, and ferrochrome ash etc. are generated. Ferrochrome ash is generated from Ferro-alloy industry and fly-ash is produced in thermal power plants are alternative materials which have the potential of being utilized in concrete as a mineral admixture. The present investigation considers the combined influence on strength of concrete using various percentage fly ash and ferrochrome ash as partial replacement of cement. Experiments are carried out to get mechanical properties of ordinary Portland cement by replacement of fly ash by $10 \%, 20 \%, 30 \%$ and $3 \%$ by ferrochrome ash. Mechanical properties are measured by determining compressive strength, split tensile strength and flexural strength. It can be inferred from the study that a small amount of ferrochrome ash mixed with $30 \%$ fly-ash gives higher compressive strength as compared to fly ash alone. Addition of ferrochrome ash also increases the split tensile strength of concrete. Since ferrochrome ash and fly-ash are both industrial waste, utilization of these waste materials reduced the burden of dumping and greenhouse gas and thereby produce sustainable concrete.
\end{abstract}

\section{Introduction}

Industrial waste materials as mineral admixture and secondary products might be utilized in concrete production as materials for the purpose of partial replacement of cement. As the rapid growth in the demand for cement, it has been a matter of great importance to find alternative cementitious materials as the production of cement produces $\mathrm{CO}_{2}$ during $\mathrm{CaCO}_{3}$ calcinations and by the fossil, being responsible for about $5 \%$ of greenhouse effect. The greenhouse effect can be reduced by partial replacement of cement by some waste product of such as fly ash, ferrochrome ash, silica fume, red mud and GGBS etc [1-5]. Rice husk fiery remains (RHA) and Fly powder (FA) with utilizing Steel fibre impacts on the workability, compressive quality, flexural rigidity, part elastic qualities, Acid safe test, solidness investigated by Deotale et al. [6]. Acharya and Patra [7] studied the mechanical and durability characteristics of concrete enhanced with ferrochrome ash (FrA) as a partial substitution for cement. Ferrochrome ash (FrA) is a waste product of ferroalloys industries. It is observed from the literature study that the combination of mineral admixtures can improve the mechanical strength and durability of samples of concrete. The objective is to study the combined influence of fly ash and ferrochrome ash as part cement replacement on the mechanical properties of concrete.

\section{Materials and methods}

\subsection{Cements, aggregates, water, and plasticizer}

Ordinary Portland cement (OPC), 43 Grade as per IS $8112: 1989$ [8] has been utilized. Natural river bed sand (fine aggregate) falling under grading zone III as per IS 383:1870 [9] and hard natural stone aggregates (coarse aggregate), black in color as per IS 383: 1870 were used as aggregates. Potable Water free from impurities and foreign substances or chemical compounds has been utilized for the preparation as well as curing of concrete samples conforming to IS 456: 2000 [10]. Keeping the wc ratio fixed for all concrete mixes, a polycarboxylic 
based super plasticizer has been used in the samples for the enhancement of the workability.

\subsection{Ferrochrome ash}

Ferrochrome ash (F.ash) as shown in Fig. 1 is the dust which is obtained as of the cleaning process of the industrial manufacturing units of ferrochrome. The gaseous material emitted from the furnaces of smelting of alloy of iron or Ferro contains many impurities like particles of dust, improperly burned materials like timber. A plant manufactured for the cleansing of these harmful gases is liable to process a considerable amount of particles of dust or ash which contains F.ash as the main constituent.

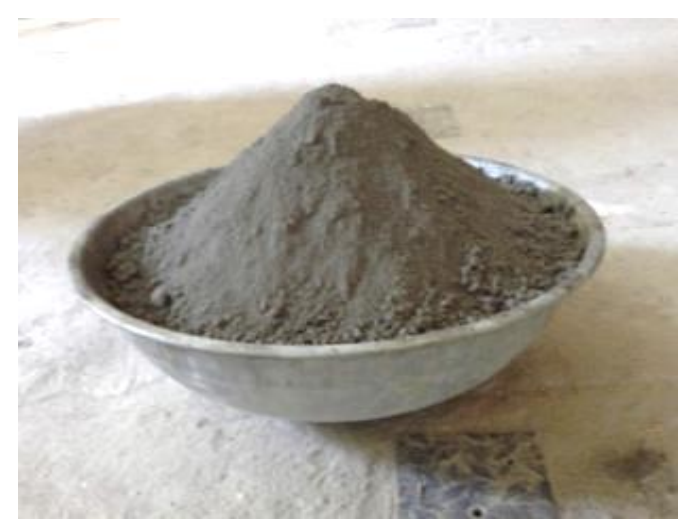

Fig. 1. Ferrochrome Ash

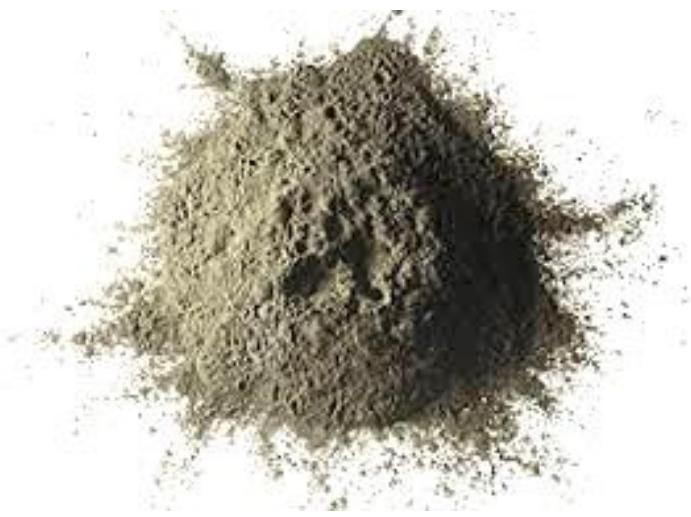

Fig. 2. Fly Ash

\subsection{Fly ash}

Fly ash (FA) as shown in Fig. 2 is a waste generated at thermal power stations. Fly ash is a powder, fine, soft and glassy material that is gathered from a corrosive case by a bag filter. Fly ash can be used in mix concrete replacing the Portland cement and it will make a low maintenance cost and environmentally friendly solution that meets performance specifications. It is possible that if fly ash is added by $20 \%-30 \%$ replacing cement then it will give better result in the different age. The physical and chemical properties of OPC, F.ash and fly ash are shown in Table 1.

\subsection{Mix proportions and Preparation of concrete specimen}

Different mix of FA, F.ash \& reference concrete samples were prepared for testing as per Indian Standards. Concrete cubes were having side $0.15 \mathrm{~m}$ for a compression test; the cylindrical specimens prepared for the split tensile strength test were having a diameter of $0.15 \mathrm{~m}$ and height of $0.30 \mathrm{~m}$. The sample size for flexural strength test was having breadth and height of $0.1 \mathrm{~m}$ and having a length of $0.5 \mathrm{~m}$. The sample strengths were tested at 7 and 28 days. The different mix proportion for M30 concrete (1: 1.23: 2.29) is shown in table 2. The samples were wrapped in sheets made of plastic post casting for a period of 1 day at $25^{\circ} \mathrm{C}$. After the specified period, the samples were taken out of their moulds and put under water at a temperature of $27^{\circ} \mathrm{C} \pm 2^{\circ} \mathrm{C}$ so that curing of the samples can occur up to the specified period of their testing.

\subsection{Test Procedure}

Slump test of the concrete mix was done for the purpose of determining its workability in accordance to IS: 73201974 and IS: 1199-1959[11-12]. The slump tests perform a vital role in the determination of the workability of samples of control mix and ferrochrome enhanced concrete samples. In this test the slump value was taken as $0.10 \pm 0.005 \mathrm{~m}$. The compressive strength test, split tensile strength test and flexural strength of the samples were performed confirming to IS: 516-1959 [13]. 
Table 1. Chemical Composition of OPC, Ferrochrome Ash \& Fly Ash (\% by weight)

\begin{tabular}{|c|c|c|c|c|}
\hline SI.No & Constituent & OPC & Ferrochrome ash (F.ash) & Fly Ash (FA) \\
\hline 1 & $\mathrm{SiO}_{2}$ & 20.61 & 19.6 & 59.00 \\
\hline 2 & $\mathrm{Al}_{2} \mathrm{O}_{3}$ & 5.028 & 11.1 & 24.18 \\
\hline 3 & $\mathrm{CaO}$ & 62.61 & 4.22 & 6.90 \\
\hline 4 & $\mathrm{Fe}_{2} \mathrm{O}_{3}$ & 3.329 & 6.06 & 3.70 \\
\hline 5 & $\mathrm{MgO}$ & 2.237 & 15.6 & 3.30 \\
\hline 6 & $\mathrm{SO}_{3}$ & 2.723 & 1.92 & 1.00 \\
\hline 7 & $\mathrm{Na}_{2} \mathrm{O}$ & 0.328 & 1.3 & - \\
\hline 8 & $\mathrm{~K}_{2} \mathrm{O}$ & 0.577 & 0.46 & 0.9 \\
\hline 9 & $\mathrm{P}_{2} \mathrm{O}_{5}$ & 0.320 & 0.06 & - \\
\hline 10 & $\mathrm{TiO}_{2}$ & 0.270 & 2.196 & 1.02 \\
\hline
\end{tabular}

Table 2. Mix Proportion $(\mathrm{Kg} / \mathrm{m} 3)$

\begin{tabular}{|c|c|c|c|c|}
\hline MATERIALS & CONTROL & FLY ASH $10 \%$ & FLY ASH $20 \%$ & FLY ASH $30 \%$ \\
\hline Mix no & N100 & N87FA & N77FA & N67FA \\
\hline Mix composition & $100 \%$ OPC & $\begin{array}{c}87 \% \mathrm{OPC}+10 \% \mathrm{FA}+3 \% \\
\text { F.ash }\end{array}$ & $77 \% \mathrm{OPC}+20 \% \mathrm{FA}+3 \% \mathrm{~F} . \mathrm{ash}$ & $67 \% O P C+30 \% F A+3 \% F . a s h$ \\
\hline Cement & 499 & 434.13 & 384.23 & 334.33 \\
\hline Ferrochrome Ash & - & 13.50 & 13.50 & 13.50 \\
\hline Fly Ash & - & 42.771 & 85.543 & 128.314 \\
\hline Water & 0.40 & 0.40 & 0.40 & 0.40 \\
\hline Fine Aggregate & 613.90 & 613.90 & 613.90 & 613.90 \\
\hline Coarse Aggregate & 1144.50 & 1144.50 & 1144.50 & 1144.50 \\
\hline
\end{tabular}

N-Normal concrete, FA-Fly ash, and F.ash- Ferrochrome ash 


\section{Mechanical Properties}

Combined effect of fly ash and ferrochrome ash on mechanical characteristics of the concrete samples for, compressive strength, split tensile strength and flexural strength containing natural find and coarse aggregate are reported below.

\subsection{Compressive Strength of concrete}

Compressive Strength is an important characteristic for determining the mechanical strength of concrete and hence necessary criteria in structural layout and detailing aspects. The average strength development of concrete cubes was studied at 7,28 and 56 days for all the proportion and presented in Fig 3 .

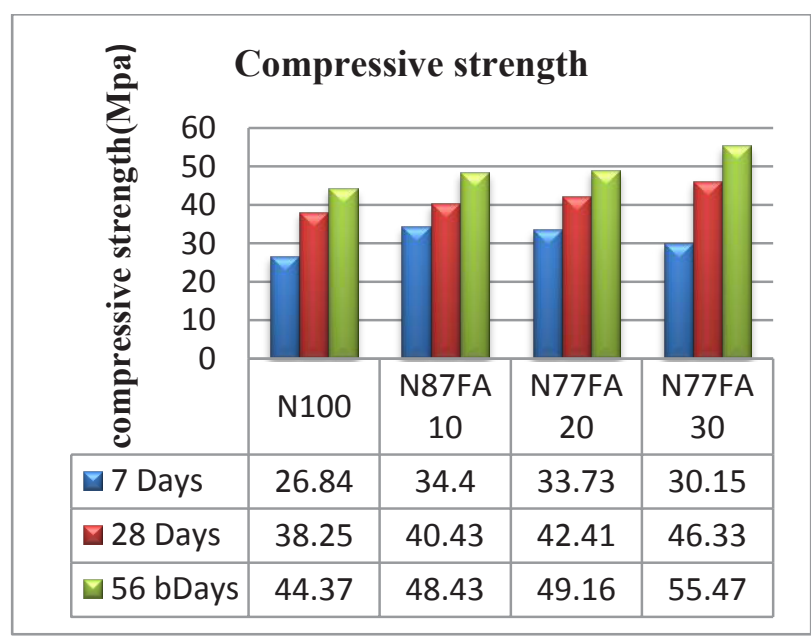

Fig. 3. Compressive strength at different ages with fly ash and ferrochrome ash

\section{Effect of Fly ash and Ferrochrome ash on compressive strength}

The suitability of Fly ash and Ferrochrome ash as cement replacement of concrete is investigated. The compressive strength of $150 \mathrm{~mm}$ cubes containing $10-30 \%$ of Fly ash with $3 \%$ of Ferrochrome ash, on the part substitution of cement was examined at 7,28 and 56 days. The results at above ages are depicted in Figure 3. The test results depicted that as a consequence of the addition of Fly ash $10-30 \%$ and $3 \%$ of Ferrochrome ash, on the substitution of cement, the compressive strength got increased at all testing periods as compared to control concrete samples. It is observed that the gain in compressive strength is in increasing order up to $30 \%$ Fly ash content. Replacement of FA $10 \%$ with $3 \%$ F.ash enhanced compressive strength $28.16,25.67$ and $12.33 \%$ at 7,28 and 56 days.
Replacement of FA $20 \%$ with 3\% F.ash enhanced compressive strength $5.69,10.87$ and $21.12 \%$ at 7,28 and 56 days. Whereas in case of FA $30 \%$ with 3\% F.ash enhanced compressive strength of $9.15,10.79$ and $25.01 \%$ at 7,28 and 56 days. Thus the results indicated that FA 30\% with $3 \%$ F.ash may be considered when a strength requirement is more than normal.

The compressive strength of the prepared concrete samples containing FA and F.ash and also the control sample got increased with age. The increment in strength in normal concrete between $28-56$ days reported $16.00 \%$. The other mixes, containing 10, 20 and $30 \% \mathrm{FA}$ and $3 \% \mathrm{~F}$.ash is reported $19.78,15.91$ and $19.72 \%$. The strength development in the mix, containing $30 \% \mathrm{FA}$ and $3 \%$ F.ash is found more with age when compared to other mixes.

The gain in strength is the consequence of the addition of FA and F.ash. The presence of $\mathrm{SiO}_{2}$ and $\mathrm{Al}_{2} \mathrm{O}_{3}$ are more in FA and F.ash which is responsible for $\mathrm{C}_{2} \mathrm{~S}$ and gives more strength in later age.

\subsection{Split Tensile Strength of Concrete:}

The average split tensile strength development of concrete was studied at 28 and 56 days for all the proportion and is presented in Fig 4.

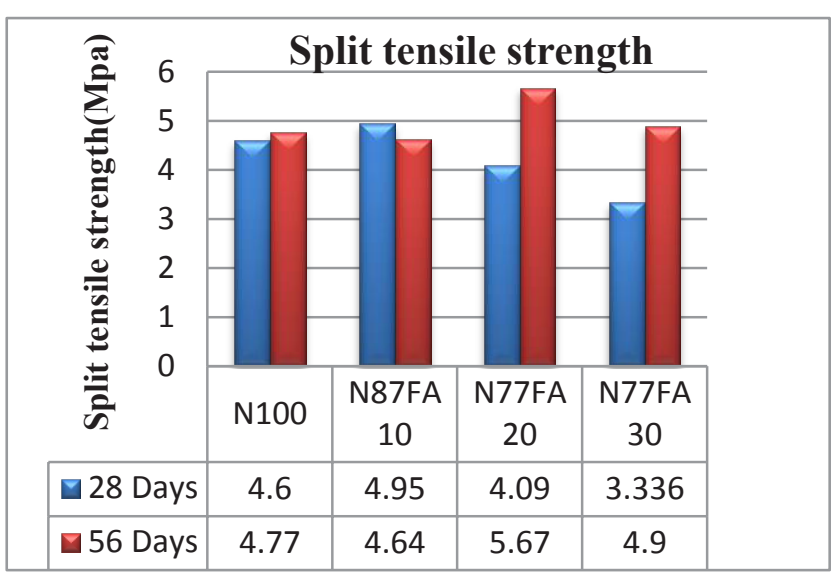

Fig. 4. Splitting tensile strength at different ages with fly ash and ferrochrome ash

\section{Effect of ferrochrome slag as coarse aggregates on split tensile strength}

The split tensile strength of cylinders containing 10-30\% of FA and 3\% F.ash, on replacement of cement was 
examined at 28 and 56 days. The results at above age have been depicted in Fig 4. The results revealed that due to the inclusion of FA $10-30 \%$ and $3 \%$ F.ash, on replacement of cement, the split tensile strength got increase in comparison to normal concrete. Replacement of cement by FA from $10 \%$ to $30 \%$ and F.ash of $3 \%$ enhanced strength $4.95,4.09,3.66 \mathrm{MPa}$ at 28 days and 4.64, 5.62 and $4.88 \mathrm{MPa}$ for 56 days. Replacement of cement by FA $20 \%$ and $3 \% \mathrm{~F}$.ash enhanced more strength 5.67 MPa at 56 days. Further, for 28-56 days the strength increased by $20 \% \mathrm{FA}$ and $3 \% \mathrm{~F}$.ash is $38.52 \%$ and for $30 \% \mathrm{FA}$ and $3 \%$, F ash is $33.33 \%$.

\subsection{Flexural Strength of concrete}

The average flexural strength of concrete was studied at 28 and 56 days for all the proportion and is presented in Fig 5.

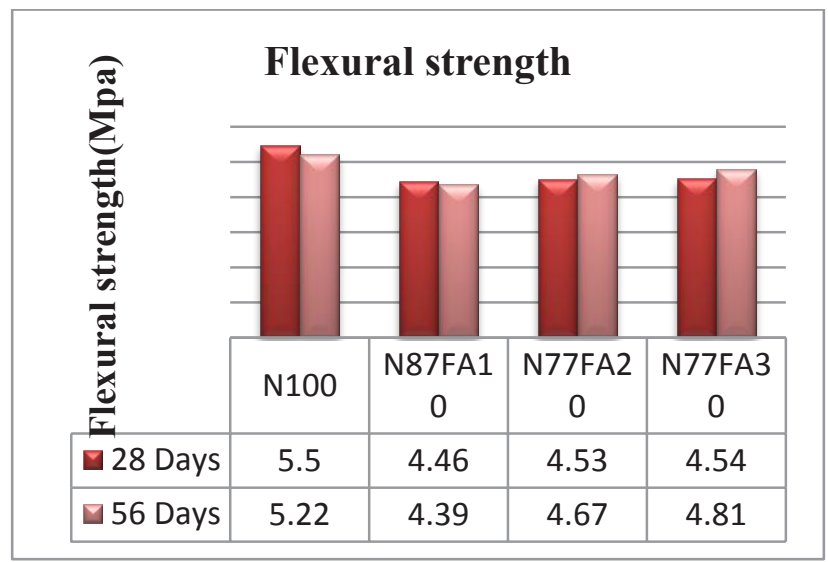

Fig. 5. Flexural strength at different ages with fly ash and ferrochrome ash

\section{Effect of ferrochrome slag as coarse aggregates on flexural strength}

The flexural strength of prisms containing $10-30 \%$ of FA and $3 \% \mathrm{~F}$.ash, on replacement of cement was examined at 28 and 56 days. The results at the above age are depicted in Fig 5. Data obtained from the study revealed that due to the addition of FA and F.ash, on the substitution of cement, the flexural strength got increased as compared to control concrete samples. It is observed that the flexural strength development is in increasing order up to $30 \% \mathrm{FA}$ and $3 \%$ F.ash. Further, for 28-56 days the strength increased by $20 \% \mathrm{FA}$ and $3 \% \mathrm{~F}$.ash is $3.96 \%$ and for $30 \% \mathrm{FA}$ and $3 \%$, F.ash is $2.00 \%$.

\section{Conclusion}

As per the current research, it is visualized that samples of concrete with fly ash and ferrochrome ash Cement +
$30 \%$ Fly Ash $+3 \%$ Ferrochrome Ash, has the maximum compressive strength. The sample having an age of 56 days yielded the highest compressive strength for the partially replaced concrete. Compressive strength is directly proportional to flexural strength in this study, and it was also observed that the monetary requirements for the manufacture of concrete with OPC are significantly more than that of concrete produced by partial replacement of its constituents.

- The compressive strength increases with the increment in the proportion of FA and F.ash increases as partial replacement of cement.

- $\quad$ There is an increase of $39.45 \%, 49.43 \%$ compressive strength from 7 to 28 days and 56 days respectively in optimum use of $30 \% \mathrm{FA}+3 \% \mathrm{~F}$.ash replacement with cement.

- Further, an increase in split tensile strength by $33.33 \%$ and flexural strength by $2 \%$ from 28 days to 56 days

\section{References}

1. Mehta P K and Malhotra V.M 2002 HighPerformance, High-Volume Fly Ash Concrete. Supplementary Cementing Materials for Sustainable Development Inc (Ottawa, Canada ) p 101

2. Namagga and Rebecca A. Atadero 2009 Optimization of Fly Ash in Concrete: High Lime Fly Ash as A Replacement for Cement and Filler Material (World of Coal Ash (WOCA) Conference, May 4-7, Lexington, KY, USA)

3. Gengying Li and Xiaozhong Wub 2005 Influence of fly ash and its mean particle size on certain engineering properties of cement composite mortars (Cement and Concrete Research 35) p 1128-1134

4. Siddique Rafat 2005 Effect of fine aggregate replacement with Class $F$ fly ash on the mechanical properties of concrete (Cement and Concrete Research 33) p 539-547

5. Sata Vanchai, Chai Jaturapitakkul, and Kraiwood Kiattikomol 2007 Influence of pozzolan from various by-product materials on mechanical properties of high-strength concrete (Construction and Building Materials 21) p 1589-1598

6. Deotale, R. S. Sathawane, H. And Narde, A. R 2012 Effect of Partial Replacement of Cement by Fly Ash, Rice Husk Ash with Using Steel Fiber in Concrete (International Journal of Scientific \& Engineering Research) p 3 
7. Acharya, P. K., Patro, S. K 2016 Use of ferrochrome ash (FCA) and lime dust in concrete preparation (Elsevier Ltd., Journal of Cleaner Production 131) p 237-246

8. IS: 8112-1989, 43 Grade Ordinary Portland CementSpecification, Bureau of Indian Standards, New Delhi, India,

9. IS: 383-1970, Specifications for Coarse and Fine Aggregates from Natural Sources for Concrete, Bureau of Indian Standards, New Delhi, India.

10. IS: 456-2000, Plain and Reinforced concrete - Code of practice, Bureau of Indian Standards, New Delhi, India.

11. IS: 7320-1974, Specifications for Concrete Slump Test Apparatus, Bureau of Indian Standards, New Delhi, India.

12. IS: 1199-1959, Methods of Sampling and Analysis of Concrete, Bureau of Indian Standards, New Delhi, India.

13. IS: 516-1959, Methods of Tests for Strength of Concrete, Bureau of Indian Standards, New Delhi, India. 